\title{
SAN PEDRO DE HUANCARPATA (HUARI, ÁNCASH): UN CASO DE HETEROGENEIDAD A PARTIR DE TRES DEIDADES PREHISPÁNICAS
}

\author{
SAN PEDRO OF HUANCARPATA (HUARI, ÁNCASH): A CASE OF \\ HETEROGENEITY FROM THREE PREHISPANIC DEITIES
}

\author{
Vidal Guerrero*
}

\begin{abstract}
El presente trabajo explora los complejos procesos de resemantización de la fiesta patronal de San Pedro de Huancarpata en la provincia de Huari, región Áncash, Perú. Para ello se examina la tradición oral enfatizando la hagiografía del santo, sus actantes, las conexiones con el discurso de los primeros catequistas que arribaron a esos lares, los concilios limenses, las campañas de extirpación, la pervivencia de la cosmovisión quechua y las múltiples formas de resistencia cultural. Asimismo, se hace una lectura etnohistórica y etnoliteraria respecto de las deidades Huari, Libiac y Llamoq, destacando su gestación y desarrollo que nos permita entender el sentido de la fiesta patronal en Huancarpata. A partir de estos elementos, se pretenden explicar la adición, sustitución y superposición que sufrió el otrora hirka Llamoq, deidad prehispánica, para finalmente transferir sus atributos originarios al nuevo elemento de culto: San Pedro.
\end{abstract}

Palabras claves: Hirka Llamoq, Libiac, Huari, San Pedro.

The present work explores the complex resemantization processes of the religious feast of San Pedro of Huancarpata in the province of Huari, Ancash region, Peru. The oral tradition is examined to do this exploration, emphasizing the hagiography of the saint, his actants, the connections with the speech of the first catechists who arrived in those parts, the Lima councils, the campaigns of extirpation, the survival of the Quechua worldview and the multiple forms of cultural resistance. Likewise, an ethnohistoric and ethno-literary reading is made about the deities Huari, Libiac, and Llamoq, highlighting its gestation and development that allows us to understand the religious meaning of the feast in Huancarpata. From these elements, it is intended to explain the addition, substitution, and superposition that the former hirka Llamoq, prehispanic deity, suffered to finally transfer its original attributes to the new cult element: San Pedro.

Key words: Hirka Llamoq, Libiac, Huari, San Pedro.

\section{Introducción}

Los ciclos míticos en el mundo andino sirven para organizar las explicaciones acerca del origen de la vida, la cosmovisión, las nociones del tiempo y el espacio, la materia y el kamaq o la vida y la muerte. El pensamiento andino tan proclive a la hierofanía (Eliade 1974) y a la construcción de ideologías mágico-religiosas, ha tenido su manifestación en las prácticas sociales y religiosas como el culto a sus ancestros y a sus dioses tutelares de la comunidad, del ayllu o de los grupos sociales concentrados por razones políticas o económicas. (Sánchez 2014, López y Millones 2008)

La documentación etnohistórica, etnográfica y las evidencias arqueológicas permiten asumir que desde las épocas prehispánicas estos grupos humanos, asentados en la cordillera de los Andes, tuvieron una visión holística y panteísta del cosmos donde sus deidades conocidas como wamanis, apus, achachilas, hirkas o awilus fueron parte de esa visión tripartita: Hanan Pacha, Kay Pacha y Uju Pacha. Dichas deidades, panandinas, en muchos casos, han sufrido diversos procesos de resemantización debido a los desplazamientos sociales y a complejas condiciones ecológicas que les ha permitido adicionar semas, perder o invisibilizar atributos que ulteriormente les ha servido para asegurar su vigencia.

En este trabajo se presenta un caso particular de manifestación religiosa recogido en el Centro Poblado de Huancarpata, perteneciente al distrito de Cajay en la provincia de Huari, región Áncash, Perú. En esta zona se asentaron dos etnias denominadas huaris $\left(\right.$ llactas $\left.^{1}\right)$ y llakwash, aproximadamente entre $200 \mathrm{a}$. C. hasta 1.500 d. C. Estos grupos humanos formalizan la dualidad, los principios de complementariedad y reciprocidad así como el yanantin (dualidad) y el

\footnotetext{
* Universidad Nacional Santiago Antúnez de Mayolo, Áncash, Perú. Correo electrónico: vidalguerrerot@ hotmail.com
} 
tinkuy (encuentro), categorías tan cruciales en el universo andino. Asimismo, viabilizan las relaciones ontológicas construyendo alteridades e isotopías en un todo armónico e interactivo donde las relaciones con los vivos y los muertos, los dioses y los hombres o los animales y los hombres, se manifiestan en un espacio sacro y sobresaturado de símbolos.

En diversas evidencias arqueológicas se ha podido constatar que aquellas etnias han establecido sus centros administrativos, religiosos y políticos teniendo como punto de partida la ubicación de wankas (rocas), cerros y lagunas. Estos espacios dan cuenta de las dinámicas culturales que ha existido y donde el factor exógeno ha servido para convertir a sus ideologías en un entramado complejo que asimiló elementos como la música, la religión, la cosmovisión, la danza, la gastronomía, la indumentaria, la lengua, la flora, la fauna, etc. Precisamente, esta característica es la que se advierte en las festividades de San Pedro de Huancarpata que representa la unidad en la diversidad (pues condensa a diversas etnias), la armonía en el caos (representa el equilibrio en la vida del runa) y la dialogía frente a la monología (porque la devoción y la carnavalización suscita la interacción a todo nivel) frente al discurso autoritario del invasor.

Por lo señalado, se plantea la hipótesis, absolutamente provisoria: el patrón de Huancarpata condensa a los dioses de la etnia de los huaris y los llakwash, pese a ser de distintas zonas. La ubicación de su templo, el origen del santo, la música y los ritos que se manifiestan en la actualidad tienen conexiones con el hirka Llamoq, deidad regional que se superpuso, en la zona de Conchucos, al dios Guari $^{2}$ y a Libiac, dios del rayo.

\section{Huari, Guari, Wari}

Torero (1993), Asencios (2013), Carranza (2003) y Cerrón-Palomino (1987) señalan que la voz "huari" se relaciona con el dios de la agricultura y de la civilización, así como se suele asociarla con las deidades de la cultura Chavín (provincia de Huari); incluso Duviols (1973) señala que Chavín de Huántar fue su templo principal. Además, en la información que ofrecen Arriaga [1621] (1920) y Cobo [1631] (1956) se aluden a hombres gigantes que habrían poblado estas zonas a los que se refieren como huarirunas, hombres naturales de Huari. Esta información se complementa con el otro grupo de habitantes que presumiblemente vino a morar por la zona de Conchucos identificado como los llakwash, a quienes se les describe como extraños o extranjeros que habitaron la parte alta de las montañas y se dedicaron básicamente al pastoreo, la caza y la fábrica de armas.

Las primeras informaciones de los grupos humanos de esta zona vienen del testimonio de Domingo Rimachin que se produjo el 5 de agosto de 1656 en un proceso seguido por el bachiller Bernardo de Noboa, cura de la doctrina de San Pedro de Ticllos. Ante las preguntas referidas a la persistencia de los cultos a sus mallquis (difuntos), así como acerca de su origen, el interrogado responde: “...los dichos indios llaquaces fue una nación que bibio siempre en las punas y los guaris fueron de nación gigantes barbados los quales criuo el sol y a los Llaquaces el rayo" (Duviols 2003: 304).

Como se puede desprender, según esta versión, tanto huaris como llakwash proceden del lago Titicaca; los primeros fueron criados por el Sol y los segundos, por el rayo. Estos vivieron en las partes altas, y la llanura fue territorio de los huaris. Esta conclusión provisoria es corroborada con la confesión de Juan Chuchu que señala: "saue que los a oido y aberlo visto que los llaquazes adoran al Rayo y a los Guaris por hijos del Sol y que Pedro Ripa guarda vn ydolo que llaman el rayo por decir haber caido del cielo..." (Duviols 2003: 275). Entonces se asume que hay dos dioses para las etnias que responden a sus hábitats y a sus relaciones económicas y sociales. Sin embargo, en la confesión de Juan Guaraz, en el pueblo de Santo Domingo de Paria, es cuando se va a conocer el nombre del dios de los llakwash. Este testimonio es del 8 de agosto de 1656, hecho a Bernardo de Noboa, donde Guaraz, señala lo siguiente:

\section{“... y los demás tienen por pacarinas a} Libiac y al Guari por haber sido sus primeros fundadores y malquis que vinieron del Titicaca por el Libiac y los Guaris fueron criados en sus propios pueblos y asi tienen sus pacarinas los llaquazes en las punas y los Guaris en sus pueblos".

(Duviols 2003: 274).

Esta declaración es corroborada con las versiones de Arriaga [1621] (1920) y Hernández Príncipe [1621] (1923).

Asimismo, el visitador de idolatrías Estanislao Vega Bazán señala que: 
“... el dicho Huari fe conuierte hoy en dia en muchas formas de hombre, y de culebras, y en efpecial se convierte en ayre rapido, $y$ que en efta forma de aire anda todos los dias, gouernando el mundo, y dando buelta por el y dando enfermedades, culebras y otras cofas a los que no le adoran ni le firuen, y dando vida y falud a los que firuen, dogmatizando que era Dios y criador de la tierra (Venturoli 2011: 57).

A estos datos se añade el mito recogido por Santiago Antúnez de Mayolo acerca del origen de los huaris $^{3}$, donde se vislumbra la tríada cosmológica del mundo de arriba, el mundo de aquí y el mundo de abajo. Hay una pacarina por donde emergen los huaris. Su apariencia roja que puede denotar el fuego, nos hace pensar en su Dios (el Sol) en las versiones de Rimachin y Chuchu. Su asentamiento en las llanuras se asocia con la agricultura. Más aún, el agua, el viento y los amarus son elementos en los que se transmuta Huari en la versión de Estanislao Vega Bazán y que en este mito se presentan como elementos centrales.

En versiones más recientes consignadas por Ventureli (2011), los huarirunas surgieron de dos lagunas: Purway (Acopalca, Huari) y Reparin (Cajay, Huari). Ambas zonas están rodeadas de restos arqueológicos que hablan de las primeras poblaciones que sospechamos son los llakwash y llactas. Su asentamiento en los relatos etnohistóricos ${ }^{4}$ aparece con el nombre de Naupa Marca y Marcajirca, estudiado ampliamente por Ibarra (2004, 2009 у 2016).

También Yauri (2016) señala que Guari o Huari fue un dios que estaba relacionado con el agua, los sembríos y el viento. Lo considera un dios panandino que señoreó en las zonas de Conchucos y el Callejón de Huaylas. Afirma que es una advocación del dios del rayo, sustituido, tras la invasión española, por la imagen del Señor de la Soledad de Huarás, señor de las aguas, del viento y las tempestades; controlador de los terremotos y las sequías.

Entonces, la voz "huari" significó inicialmente áspero, grotesco, primitivo. Posteriormente se asocia con la fundación de pueblos ${ }^{5}$ civilizados y diestros en la agricultura. El dios Guari o Huari, puede convertirse en hombre, culebra y aire. Fue el dios de los huaris o llactas, según Limón (2017), en oposición a los llakwases. El hecho de que tengan como origen al lago Titicaca y que se desplacen hasta estas zonas de Áncash, se puede explicar desde la historiografía como producto de las guerras y los desplazamientos humanos donde el factor cultural también se desplaza a modo de semiósferas ( Lotman 1996).

\section{Libiac}

Llamado Illapa (la raíz "illa" significa centellear) por los incas, Catequil por los llakwash en Huamachuco, y Libiac (llipllaq relampagueante) en la región Huaylas. Según la versión del licenciado Rodrigo Hernández Príncipe, es una trilogía. Señala:

“... a su salvo adoraban al Rayo, en quien representaban y consideraban tres personas, conviene a saber: Llíviac, del Rayo; Ñámoc, la de su padre; Uchu Llíviac, la del hijo, de quien fingen estos indios llachuases tener su origen y procedencia". (Duviols, 2003: 755-756).

Como se lee en las declaraciones de Hernández, en la provincia de Huaylas (según división política del siglo XVI) aparece el dios Námoc, Llamoc o Llamoq como padre de Libiac vinculado con el rayo, el trueno y el relámpago. Detalle que no se registra en las otras zonas de asentamiento de los llakwash. Pensamos que Llamoq es una advocación del mismo Libiac o Pariaqaqa que están asociados con el agua y el pastoreo. Es importante también puntualizar que en Dioses y hombres de Huarochirí, según Herrera (2016) Libiac Cancharco, está asociado con el agua y fue objeto de culto, corroborado durante las evangelizaciones en el siglo XVI. Por consiguiente, aunque el dios del rayo está considerado como el tercero más importante en la jerarquía de dioses en el Cuzco, por debajo de Wiracocha e Inti, no se puede soslayar la importancia que tuvo para los llakwash que consideraron a Libiac como su dios principal ${ }^{6}$. Los territorios que abarcó fue Áncash, Huaylas, ciertas zonas de la provincia de Cajatambo, Cajamarca y Recuay aunque con nombres diferentes. Su presencia también se le asocia con la guerra, pues recordemos que en la tradición de Huarochirí, Pariaqaqa (representación del agua, los rayos y los truenos) se enfrenta a Huallallo Carhuincho (fuego), y lo derrota a base de tormentas y tempestades.

Respecto de su origen, hay dos versiones que cobran importancia: la de Andrés Chaupis Yauri del 5 de julio de 1556 donde declara que de 8 ventanas salieron hombres barbados y se ubicaron en la 
cordillera Huayhuash. La otra versión corresponde a Santa Catalina de Pimachi (25 de abril de 1556) que señala que Libiac cayó del cielo en forma de rayo. Posteriormente también se ubica en la cordillera de Huayhuash. (Duviols, 2003)

Así también, Cardich (2014) identifica a Libiac con el nombre de Yana Raman o Libiac Cancharco que

"por su origen y nombre constituiría un verdadero dios del Rayo; Cae del cielo en forma de una criatura recién nacida y en 5 días (el número que preside los principales actos de los dioses y de los ritos en la Sierra Central) se hace grande. Llega a ser el dios principal de los pastores, particularmente de los yaro-llakwash" (79).

Como vemos, los nombres y la jerarquía pueden variar, pero la simbolización permanece inalterable. Libiac Cancharco o Yana Ramán cayó en forma de rayo, sobre la cima de la cordillera, y en versión de Francisco Marcapari de la localidad de Cauri del ayllu de Yachas (Huánuco), hecha el 9 de marzo de 1615 (Robles, 2004), fue criado por un pastor de nombre Antuchuca del pueblo de Guacra. Los llakwash, para recordar a este pastor y reciprocar a Libiac Cancharco, realizan ritos tres veces al año. Las fiestas que están amenizadas por el pinkullo y la tinya se ejecutan en diciembre para invocar su poder y se produzca la lluvia; en febrero para preparar las sementeras; y en junio, la fiesta de Corpus Christi que es para agradecer las cosechas.

\section{Hirka Llamoq}

Llamoc, Llamoq, Llamoca o Ñamoc, de acuerdo con los documentos oficiales y testimonios de la época, es un cerro que se ubica en la parte este del distrito de Cajay en la provincia de Huari, entre Marcajirca y el río Huaritambo. Tiene una altitud de $4.215 \mathrm{msnm}$ y está rodeado de pueblos como Chinchas, Huayllabamba y Huancarpata. La imponencia del hirka (cerro) se observa desde la ciudad de Huari. Quizá las primeras versiones de este hirka se obtengan de Hernández Príncipe en 1621 (1923: 57), que señala lo siguiente:

Un adoratorio rodeado de cantería y en medio hecho un caracol estaba su respetada y principal huaca llamada Llamoc, que era una piedra a modo de una calavera tan pesada como fiera que mirarla ponía horror estaba rodeada de muchos sacrificios; adorábanla con airiuas y trompetas estos llactas y era huaca de la madre del cachique. Y los deste ayllo dijeron proceder de esta huaca y su hijo Conopa, que era una piedra larga, soterrada un estado de fondo junto a la población, y sobre ella estaba la peana de la cruz que Fray Francisco había puesto, habiéndole dado los indios otra piedra por esta huaca. En el dicho asiento de Llamoc estaban dos depósitos de los gentiles Huari Villca y haca Villca, a quienes los cojos y tullidos pedían sanidad, porque dicen que ambos habían sido contrahechos, y así quiso Dios hubiese en esta pacha más cojos que en otras.

De la cita se colige que el hirka Llamoq es una deidad que creó a las etnias, poderoso dios que no solo protege la vida de los hombres y los animales, sino que provee de salud, equilibrio y armonía en el cosmos. Su ubicación estratégica es ocupada por los llakwash. Según Ibarra (2004), los nombres de algunos hirkas aluden a los nombres de los antepasados de la etnia y el lugar de residencia está conformada por

"estructuras ceremoniales. En el valle del Puchca, en el distrito de Cajay, existe un cerro al que los pobladores llaman Llamog. Creemos estar aquí ante la transformación de una huanca en un cerro, vale decir, ante una huanca gigante" (325).

En trabajos arqueológicos posteriores del mismo Ibarra (2016) se advierte que el hirka Llamoq dataría del periodo intermedio tardío (1.000-1.476 d. C.), cuando el señorío de los Waris había declinado y muchos curacazgos empezaron a florecer. Los trabajos arqueológicos que consigna Ibarra dan cuenta de una etnia que habitó la cima y las faldas del hirka Llamoq:

"La cima misma de Llamoq está conformada por una plataforma de forma rectangular en la cual actualmente se halla una cruz católica. Una serie de calas ( 40 x $50 \mathrm{~cm}$ ) revelaron la presencia de cerámica decorada (pintada) pero sin diseños" (197).

Pensamos, al igual que Ibarra (2004), que el hallazgo de tumbas intactas, con sus osamentas y 
cráneos visibles hasta la actualidad, pueden evidenciar que los evangelizadores y extirpadores no fueron escrupulosos en su trabajo. Al parecer, estaban muy concentrados en las reducciones o lugares de mayor importancia. Por su parte, Venturoli (2011) destaca la importancia de este hirka para los huarinos porque condensa la memoria, el pasado y la identidad y actúa como un gran "mnemagogo" (técnica que consiste en recordar algo por asociación).

En los trabajos de campo, Venturoli, detectó que los pobladores le llaman awilu (abuelo), para destacar la progenie, sus vinculaciones religiosas y su respeto y sumisión. "Llamoq es el padre de Huari, es quien cuida al pueblo", asevera Venturoli (239), y establece una dialogía entre la vida de los huarinos con el poder del hirka. Por eso, cada primera semana de mayo suben a la cima para orar, cantar, bailar y dejar ofrendas. Lo consideran el protector de Huari, de sus familias y causa de la reproducción de sus ganados. Venturoli destaca el adjetivo "manso" del hirka Llamoq para oponerse a salvaje, bárbaro e inmisericorde. Señala que las cruces que se colocan en la cima de este y otros hirkas como Cerro Monje o Cruzjircan ubicados al noroeste de Huari, han servido para humanizarlos $\mathrm{y}$ volverlos benevolentes.

Los hirkas, rucus o chakwas (cerros, viejos o viejas) o más cariñosamente identificadas como los awilus, abuelos en la provincia de Huari, son los gestores de las identidades locales, equilibradores del cosmos y de la vida. Han logrado incorporarse exitosamente a la iconografía cristiana, acompañando al runa en su periplo histórico: desde ser llakwash o llactas, a ser considerados indios, luego campesinos, posteriormente andinos, hasta terminar como sujetos biculturales que entran y salen de la modernidad.

\section{Concilios limenses y las campañas de extirpación}

La invasión española produjo un colapso en el sistema social, político, económico y religioso de las sociedades andinas. Tras el dominio militar en el siglo XVI, se produjo una campaña encabezada por los curas, doctrineros y los llamados extirpadores de idolatrías. Inicialmente la denominaron como las campañas de evangelización, pero al advertir que los runas seguían venerando a sus ídolos, se procuraron nuevas estrategias para la evangelización y la doctrina que implicaron muertes, torturas, castigos y sanciones que fueron acompañados con la destrucción de algunos adoratorios, los ídolos y una persecución implacable contra los sacerdotes andinos. Para ello se creó un cuerpo de leyes, ordenanzas, edictos y sínodos que reforzaron la evangelización (Griffiths 1989). Quizá La Instrucción para curas de indios de 1545 sea el primer documento que intentó contrarrestar a lo que los españoles llamaban acciones idolátricas. Sin embargo, debió establecerse los famosos Concilios Limenses para evaluar la vigencia de la religiosidad andina, planificar las estrategias de evangelización e incorporar a la figura del extirpador de idolatrías. Para ello se establecieron tres concilios limenses: en 1551-1552, la primera; $1567-1568$, la segunda; y la tercera en 1582-1583. Este último fue el que tuvo mayor impacto hasta finales del siglo XIX cuando fue revisado y actualizado en el Concilio Plenario Latinoamericano de 1899 (Bartra 1982).

Según Duviols (1986, 1993), Acosta (2016) y Borges (1960), la aparente buena marcha de la labor pastoral fue interrumpida intempestivamente cuando en 1607 el cura Francisco de Ávila, encargado de la parroquia de San Damián en Huarochirí, denunció la existencia de hechiceros, brujos y brujas que adoraban a sus ídolos de manera clandestina. Y que el indio Hernando Páucar era el sacerdote encargado del culto a sus ancestros. Su denuncia fue acogida rápidamente y miembros de la Compañía de Jesús lograron requisar diversos objetos que empleaban para ejecutar sus ritos. Posteriormente, este hecho le permitió a Francisco de Ávila coronarse como el primer extirpador de idolatrías nombrado por el arzobispo Lobo Guerrero. El equipo de extirpación estuvo compuesto por un fiscal, un notario, uno o dos sacerdotes de alguna orden, un indio que dominara el castellano y un secretario para registrar las declaraciones. Es valiosa la información con que se cuenta a partir del siglo XVII, pues en cartas, edictos, informes, instrucciones, documentos oficiales y orientaciones pastorales existe información acerca de la naturaleza de las deidades y la suerte que corrieron tras los hallazgos. Solo como dato, el cura Ávila, en su afán de demostrar su acusación, requisó más de 400 ídolos solo en la jurisdicción de la iglesia de San Damián, incluso señala que se "cansó de contar", y en las intervenciones oficiales ya no los consignó. Esta información obra en crónicas y documentación eclesial de la época.

\section{San Pedro de Huancarpata}

Cajay es uno de los dieciséis distritos que conforman la provincia de Huari (Áncash). Se ubica en una altitud de $3.175 \mathrm{msnm}$ y posee una topografía 
con declives variados, casi ausencia de mesetas, donde los caseríos se ubican en las pendientes con ligeras pampas acondicionadas para la agricultura. Hay ríos, riachuelos, manantiales y humedales (Ushnu) que garantizan la producción agrícola en cualquier época del año.

Huancarpata es un caserío que forma parte del distrito de Cajay. En su jurisdicción se encuentran evidencias de los primeros hombres que poblaron esta zona. Así, hay pinturas rupestres en Quillarumi (Reparin), Ushcugaga, Huaritambo, Marcajirca y Quellcaymachay. Según Ibarra (2004) hay restos arqueológicas de los periodos del horizonte temprano e intermedio tardío en Marcamarca y Pacpacru (entre Cajay e Illauro), fortificaciones como Charac (entre Illauro y Queroragra) y otros restos como el que hallamos en nuestro trabajo de campo (2019) en la población de Ushnu ${ }^{7}$ (básicamente, chulpas y fortificaciones simples). Asimismo, hay poblaciones como Huaritambo y caminos como el Qhapaq Ñam, incanani o camino de los incas que prueban que fue una zona de tránsito permanente. También hay manantiales, cuevas, rocas y hirkas como el Llamoq a quien veneran grupos sociales fuera de la jurisdicción de Huancarpata.

La voz "huancarpata" está formada por dos palabras: "wankar" y "pata". La primera consta de dos morfemas: "wanka" que significa "piedra elevada, levantada o rígida" y "r" sufijo que significa adoración o rito. Mientras que la voz "pata" alude a un "lugar plano en lo alto". También se consigna como acepción de la voz "wankar", a un tambor que se ejecuta en las fiestas patronales. Entonces el significado aproximado de la voz huancarpata viene a ser: ritos a una piedra o roca que se desarrollan en una meseta o ritos en una meseta que se ejecuta con una especie de tambor. Ahora bien, se había señalado que el hirka LLamoq, según los testimonios de Rodrigo Hernández Príncipe, recibía veneración por parte de los llakwash y que era una piedra. Entonces los pagos, sacrificios o rituales se hacían al costado de la wanka o al pie del hirka. Es importante precisar que el pueblo de Huancarpata se asienta sobre una meseta a diferencia de la capital del distrito, Cajay, que está en una zona empinada y con una geografía

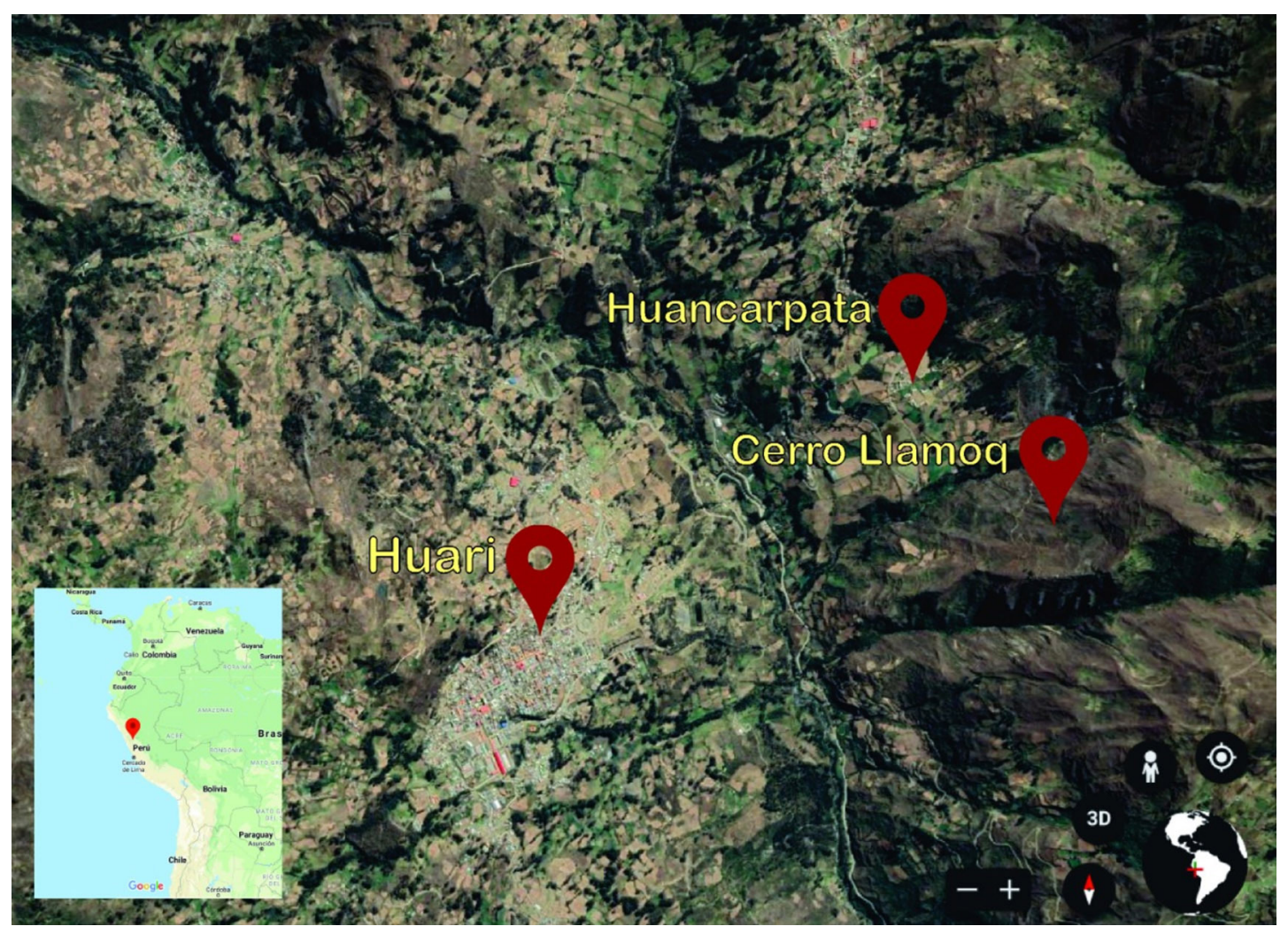

Figura 1. Ubicación geográfica del caserío de Huancarpata (Huari, Áncash). 
zigzagueante. De ahí que la acepción encaje en el contexto geográfico y social.

Asimismo, la labor fundamental en las campañas de evangelización y las de extirpación fue desterrar (o destruir) los cultos, los dioses e imponer la religión cristiana. Para ello los concilios limenses y los sínodos sirvieron para orientar o establecer las bases de la doctrina católica. Fue una labor titánica al inicio, pero relativamente "sencilla" porque los santos, los cultos y la ideología cristiana tuvieron un encuentro feliz con la wanka, el rito, la meseta y la deidad. Respecto de estos encuentros, Escalante (2016: 84), comentando los propósitos de José de Acosta, señala:

"Acosta observa no solo que la idolatría o las costumbres idolátricas no pertenecen al pasado, sino que estas son pasibles de transformarse, de adaptarse y ser permeables a la nueva religión, con la que entran en contacto; es decir, las costumbres idolátricas se amoldan a la nueva realidad y de este modo, aseguran su supervivencia".

En efecto, se amoldaron a partir de procesos de sustitución del dios andino con el dios cristiano, del rito con el culto católico, el espacio sacro andino sirvió para la superposición de la nueva iconografía occidental divina ${ }^{8}$. Salvo algunos detalles, la liturgia cristiana es parecida; diría está saturada de contenido simbólico. La comunión es la misma. El canto, la danza y la procesión son elementos que sufren adiciones con el beneplácito de los extirpadores (Díaz, Galdames y Muñoz 2012). Entonces, Llamoq debe ser sustituido. Ignoro las razones de esta performance fallida porque dicha sustitución está más cerca de San Santiago ${ }^{9}$, que en la hagiografía medieval del cristianismo surca el cielo montado sobre un caballo y azotando a las nubes con su látigo.

Pero San Pedro es el patrón del pueblo de Huancarpata, creando aparentes aporías entre el evento y la performance (relaciones simbólicas entre Llamoq y San Pedro que no concuerdan con sus historias). Mas, en esa supuesta incoherencia, o por medio de ella, la memoria colectiva no puede ser más expresiva. Entonces ese evento nos muestra las complejas formas de representación de sus dioses. San Pedro, en la hagiografía cristiana representa al mediador entre los hombres y Dios. Es el amo de las llaves de las puertas del paraíso. Es la piedra sobre la que Jesús construyó su iglesia ${ }^{10}$. Podemos llegar a Jesús por el camino que ofrece Pedro. En territorio andino ${ }^{11}$, es el multiplicador del ganado, cura las enfermedades, fertiliza la tierra, protege a los viajeros, hay temor cuando sale de su espacio porque los hirkas no se desplazan, por eso, a menudo, es representado por San Pedrito

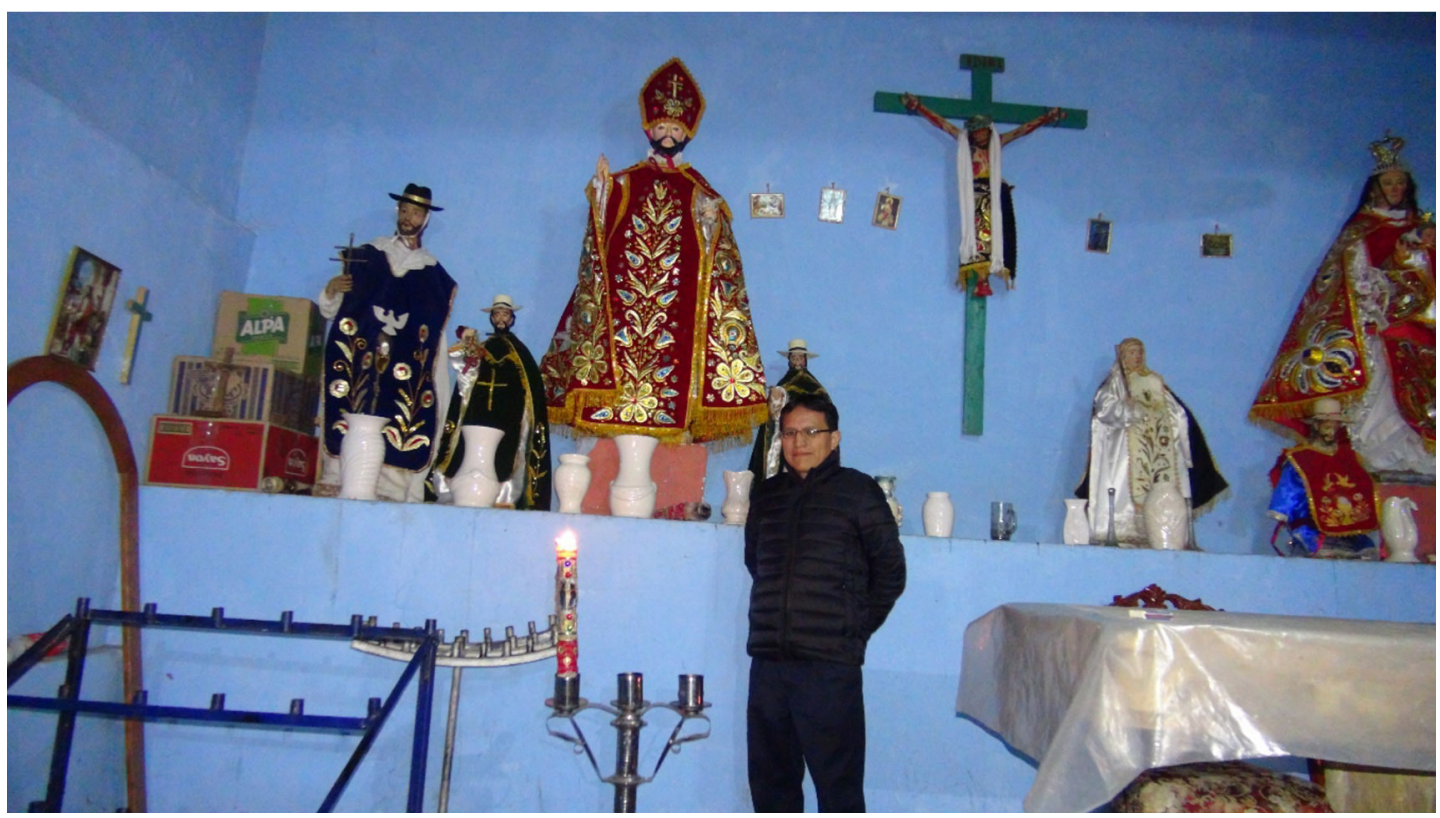

Figura 2. Interior del templo de San Pedro de Huancarpata (29/072019). 
y San Pablo, que son dos imágenes pequeñas, a manera de $i_{l l a s}{ }^{12}$, piedras pequeñas de sortilegio, también milagrosas. A estas imágenes les llaman los mellizos. Pero, como ya se explicó, las virtudes de San Pedro son una especie de condensación de las características del hirka Llamoq.

Entre los acontecimientos más relevantes durante la fiesta patronal se considera al día central de San Pedro de Huancarpata, que es el 29 de junio. Las festividades se inician aproximadamente cuatro meses antes con la famosa yamtada, cortar la leña, rajarla, dividirla. Posteriormente, dos semanas antes del día central, recogen la leña para llevarla a la casa del mayordomo. Se preparan los panes, conocida como masaracuy y beben abundante chicha de jora. El 27 de junio, por la noche, se realiza el famoso "rompe", que consiste en visitar a las casas de los huancarpatinos para invitarlos a la fiesta. Este acto es amenizado por las danzas de las Pallas y los Huaridanzas. En el presente ya desapareció la danza de los Yurihuas ${ }^{13}$. El día 28 , en la alborada, se inicia el macetakuy ${ }^{14}$, que consiste en adornar el anda de San Pedro con las diversas flores entre la que sobresale el waqank ${ }^{15}$, orquídea de 4 colores. Esta actividad es ejecutada por los pobladores de Chinchas, Huayllabamba y Acopalca. Mientras las mujeres, fundamentalmente, se trepan a las andas para tejer el cono de flores; los varones beben y conversan, algunos bailan al ritmo de la tinya y el pincullo. Paralelamente, van mudando de vestimenta al santo. Hay feligreses que esperan su turno para recibir la bendición de la imagen (esta consiste en que el sacristán o una autoridad política, levanta al santo y lo coloca sobre el cuerpo del devoto). Luego se da paso a la procesión alrededor de la plaza de Huancarpata. Por la noche se procede con la verbena.

La fiesta patronal concluye con la procesión en el día central y la corrida de toros el 29 de junio. Merece señalar que en la capital del distrito, Cajay ${ }^{16}$, creada el 13 de enero de 1961, la fiesta patronal es una emulación de la fiesta en Huancarpata y donde se venera también a San Pedro.

Respecto del origen de San Pedro de Huancarpata, Luis Tamayo Blas (77 años) sostiene que el santo apareció reiteradas veces en un pedregal, rodeado de waganku y puyaw, entonces los pobladores resolvieron edificar su templo en ese lugar. Refiere que en la cima del hirka Llamoq, un rayo destruyó la cruz e ignora desde cuándo estuvo ahí, pero precisa que la cruz actual es reciente y fue colocada por algunos pobladores de la ciudad de Huari. Asimismo, ofrece detalles de quienes habitaron la meseta, hace un recuento sucinto de la historia del pueblo y termina hablando de las flores, las danzas ${ }^{17} \mathrm{y}$ las ofrendas que se activan en la fiesta.

En la diégesis del relato de Tamayo están presentes diversos actantes como los llakwash (con quienes se identifica nuestro testimoniante), el dios del rayo, la pacarina y surge un nuevo elemento en el evento: un ushnu, antigua edificación inca para rendir culto a sus dioses. El mito informa de piedras que absorben agua y se desconoce la desembocadura. El santo aparece y desaparece. El lugar en la actualidad conserva el puyaw, planta de la zona y se observa un pedregal. El templo queda a tres o cuatro metros del ushnu, al pie del hirka Llamoq. Por su parte Valeriano Domínguez señala que la imagen fue hallada en 1650, recostado debajo de la flor waganku (Costumbres 2020).

Por su parte, Junior Santiago Córdova ${ }^{18}$ (45 años) -en el interior del templo rústico que cobija a San Pedro, de paredes de adobe, sin bóveda y con pocos asientos- nos cuenta con un brillo en los ojos y una evidente pasión por el santo: "Él es San Pedrito, muy milagroso y vive. Sí, él vive y hace muchos milagros. Lo encontraron en su debajo de la flor de qantu, pero a los mellizos no, eso es de hace poco. Los mellizos San Pedro y San Pablo lo llevamos a la iglesia de Huari".

Es importante señalar que para la doctrina cristiana, las imágenes solo son representaciones de otro ser que habita en otra dimensión. Pero la expresión "él vive" que Santiago reitera en sus mensajes que publica en su cuenta de Facebook, denota la pervivencia del culto a las pacarinas. La veneración a su santo podría ser una devoción camuflada al hirka Llamoq. También semeja esos sentimientos expresados cuando los indios sacaban a sus mallquis (momias), a sus chulpas para pasearlos por la plaza porque los consideraban vivos y elementos relacionados y complementados con el cosmos. Por eso, las procesiones durante la fiesta ( 2 o 3 veces) sacralizan ${ }^{19}$ los espacios andinos y viabilizan una nueva construcción simbólica y social. Este testimonio revelador dialoga con las letras que cantan las pallas, donde invocan al inca para acompañar a los festejos del santo. Por ello, consideramos que San Pedro de Huancarpata es el nexo entre los llakwash y los llactas, entre el Janan Patsa con el Kay Patsa o el Janan Patsa con el Uju Patsa. Es una especie de chakana que formaliza 
las dualidades allauca/ichoc, arriba/abajo, /noche/ oscuridad, barbarie/civilización, dios/demonio, frío/ calor, autóctono/foráneo, endógeno/exógeno que se manifiesta en la destrucción de la cruz durante una tempestad en la cima del hirka Llamoq.

Como se puede colegir de la fiesta patronal, lo pagano y lo eclesiástico se unen en una resemantización que la memoria colectiva construye para procesar su trauma y superar el duelo que significó abandonar sus lugares sacros y sus objetos de culto. Los españoles, inicialmente se obsesionaron con el objeto y lo convirtieron en el blanco de sus preocupaciones en sus concilios. Como precisa Torres (2018: 40): "El proceso de extirpación de idolatrías destruyó todo objeto sospechoso de ser objeto de culto pagano, se quemó ídolos, conopas, momias, pero no se erradicó el significado que guardaban estos objetos para el indígena". Entonces se podría afirmar que lograron su objetivo parcialmente porque el imaginario andino estaba casi intacto. Por ello asoma la metáfora de la transculturación inicialmente para explicar estos procesos de resemantización del cosmos andino. Posteriormente, la heterogeneidad (desde la lectura de Antonio Cornejo Polar) será una categoría más idónea para explicar mejor las rutas que tomaron estas experiencias culturales y deculturales. Así, la estrategia catequista y la respuesta andina serán dos encuentros de totalidad contradictoria en un sistema de conflicto y conciliación que prueba el dramatismo con que se construyó la nueva narrativa andina, que terminó cediendo y ocultando para lograr la pervivencia de sus dioses en la memoria histórica y mítica. Por eso, las metodologías empleadas por los catequistas y extirpadores abrieron espacios para la conservación de sus ritos y garantizaron la presencia de sus dioses.

Además, los catequistas y doctrineros enfatizaron en sus discursos la oposición bueno/malo y las contrariedades y contradicciones que suscitaron les sirvió como una fuerza coercitiva, de alineamiento al mensaje cristiano. Asimismo, se plantearon diseminar sus semas y figuraciones; pero el indígena apeló a la reificación, transformando el sentido primigenio para asumir otros significados, pero respetando los contextos. Por eso el inca (se refiere al Sapa Inca) en las canciones de las pallas, va a presenciar las festividades de San Pedro, pero en realidad encabezará los ritos a una deidad local. Es el "padre del pueblo", el hirka, el kamaq, la energía, que nunca se irá porque el tiempo es cíclico y mítico. Esta es la razón del retorno a su pacarina, que revela la testarudez de los doctrineros para repetir las mismas estrategias. Y los indios en medio de la conmoción, luchan por la pervivencia de sus espacios simbólicos. Por eso, San Pedro no abandona su templo porque tiene la llave del paraíso. El templo es la vía, es la pacarina para ingresar a la vida eterna. Una repetición de esas pacarinas son las lagunas Reparin y Purway por donde salieron y se sumergieron desde hombres hercúleos y poderosos hasta santos y santas como se lee en los ciclos narrativos.

Aparentemente los huaris, de otras edades, fueron desterrados primero por Libiac, dios del rayo, luego por el hirka Llamoq, que venció a los dioses locales y se transformó en un dios regional. Por eso las disputas por San Pedro, que podría ser el nexo, el shaman, el sacerdote indígena que invoque a Llamoq para lograr su benevolencia. Recordemos que Pedro en la doctrina cristiana es el intermediario, pero también es el sustituto de Jesucristo. En la Biblia se encuentra el mensaje textual donde el rabino le da plenas potestades (Mateo 16: 19) y refuerza el rol de San Pedro y la sospecha de su doble misión: intermediar o sustituir.

En nuestras hipótesis, la resemantización parte desde el imaginario que se formó en su momento sobre el hirka Llamoq: un dios que cayó a la tierra en forma de rayo y que se transformó en el dios de los llakwash que vivían en las partes altas de las mesetas. Pero los llactas persuadieron a los llakwash para que bajaran a sus pueblos. De esta manera se demuestra, siguiendo a Lotman (1996), que en el éxodo también se desplazó el hirka Llamoq que terminó sustituyendo a Guari. En otro relato denominado "Usha hitga: el regalo del apu Llamoq" (Huerta 2005), se señala que el hirka Llamoq derrotó a Wayra, dios del viento para propiciar el retorno del agua ${ }^{20}$. Este dato podría plantear la hipótesis que los llakwash fueron también guerreros y los llactas agricultores, artesanos o tejedores. Definitivamente en una confrontación, los llakwash pudieron triunfar cómodamente e imponer su cultura. Mediante cualquiera de las dos posibilidades, el hirka Llamoq logró extender sus dominios hasta Acopalca, Huaritambo, Cayas, Chinchas, Ushnu, Huayllabamba e incluso el mismo Huari. Mas, se produce la invasión española cuando su irradiación estaba en ascenso. He ahí la razón de que no abarcara toda la zona sierra de Áncash y tampoco el culto estuviera instituido definitivamente. Su ajenidad le obliga a tener un intermediario, pero también un sustituto con plenos poderes y que gozara con la 
conformidad de los catequistas. En la hagiografía católica solo puede ser San Pedro. Por eso la razón de reiterar las virtudes del santo en la memoria oral que despierta el asombro y la perplejidad en los pobladores vecinos, que sueñan con tenerlo porque no han podido sustituir ${ }^{21}$ al otrora hirka Llamoq con ninguna de sus imágenes.

\section{Conclusiones}

Las deidades tutelares perviven en la memoria histórica y mítica de los runas porque son el nexo entre el pasado y el presente de la etnia. En el caso de los dioses de las montañas, conocidos como apus en el Cuzco, wamanis en Ayacucho, achachilas en los pueblos aymaras y hirkas en la zona de Áncash; forman parte de los ciclos cosmogónicos de las sociedades andinas, interviniendo directamente en su ordenamiento jurídico, social, político y económico.

En el caso de los Andes centrales se sabe que el dios del rayo señoreó estas zonas por ser un fenómeno meteorológico que se manifiesta durante las precipitaciones pluviales y fue identificado como Libiac, Yana Raman o Catequil. Particularmente en los valles que rodean los ríos Puchca, Mosna y Huaritambo en la provincia de Huari, el dios del rayo fue venerado por la etnia de los llakwash, a la llegada de los españoles, con el nombre de Llamoq, una advocación de aquella deidad, que se fue extendiendo debido a las migraciones, a las guerras y a los factores socioeconómicos.

La hipótesis central de este trabajo sostiene que, tras la invasión española, San Pedro de Huancarpata condensó los atributos del hirka Llamoq debido a las labores de evangelización que fueron rigurosamente discutidas y elaboradas en los Concilios Limenses, los sínodos y la implacable labor de los extirpadores de idolatrías en los siglos XVI y XVII. Esta deidad aparece en diversos documentos políticos y religiosos de estos siglos, enfatizando sus poderes y ascendencia que alcanza a muchas comunidades andinas que se fueron plegando a la veneración a este dios.

La naturaleza del hirka Llamoq, su influjo y sus poderes están más cerca de la sustitución con San Santiago, asociado con el rayo, el trueno y el relámpago, es decir, un provocador de lluvias.
Sin embargo, el desplazamiento de esta deidad a zonas más cálidas, la asociación con los metales, su carácter bélico, la asunción a patrono de otras etnias como los llactas, se hizo más complejo en sus imaginario que terminaron simbolizando a San Pedro como el intermediador entre Llamoq y las nuevas comunidades incorporadas al culto de manera voluntaria o empleando la fuerza.

Los elementos que se activan en la fiesta patronal de San Pedro de Huancarpata permiten vislumbrar los códigos simbólicos complejos que se yuxtaponen, subvierten y visibilizan no solo con los objetos y personas en acción, sino que el espacio geográfico donde se ubican las lagunas, ushnus, pedregales, manantiales, montañas, ríos, aunado a la flora y la fauna complican la decodificación de los sentidos. A ello añadimos a la gastronomía, los ritos, la vestimenta y el elemento más intenso y complejo: la tradición oral.

Es así que los estudios etnográficos y los documentos etnohistóricos nos han permitido conocer que la impronta del hirka Llamoq se extiende a las illas, los ushnus, las pacarinas, las wakas, las danzas como el huaridanza y los yurihuas, los aymorays cantados por las pallas, hasta llegar a San Pedro y la hagiografía cristiana. Al instalarse en el imaginario la nueva prédica de este santo, su fama y bondades se extendió tanto que llegó a denominarse así a la planta empleada para los rituales por los sacerdotes de la cultura Chavín: el famoso cactus San Pedro conocida también en la época prehispánica como achuma. La deidad que se invocaba fue precisamente el dios rayo, Illapa, Libiac o Guari. Pero destronados estos dioses, el hirka Llamoq asumió ese rol.

\section{Agradecimientos}

A los pobladores del caserío de Huancarpata (Huari, Perú) que me acogieron con gran humildad y con deseos de referirme su memoria mítica e histórica. A Daniel Castillo Pinedo y su familia que facilitaron mi estadía y me proveyeron generosamente de comida y vivienda porque este trabajo fue un proyecto absolutamente personal, al que se plegaron muchos campesinos deseosos de que la fama del patrón de Huancarpata se extendiera fuera de sus fronteras. 


\section{Referencias Citadas}

Acosta, A

2016 "Iglesia, intereses económicos y teología de la dominación: contradicciones en la evangelización de la América española. Perú, siglo XVI”. Diálogo Andino, (49), 409-422. Recuperado de https://dx.doi.org/10.4067/ S0719-26812016000100036

Arriaga, Pablo Joseph de 1920 [1621] La extirpación de la idolatría en el Perú. C.L.D. R.H.P, Lima, Perú.

Asencios, F.

2013 "Los topónimos quechumaras y culles en una zona altoandina de Ancash-Perú”. Prensa Ancashina. Visión actual de Ancash, el Perú y el mundo 152 (32): 10-11.

Bartra, E.

1982 Tercer Concilio Limense. Facultad Pontificia y Civil de Teología de Lima, Perú.

Borges, P.

1960 Métodos misionales en la cristianización de América, siglo XVI. Departamento de Misionología Española, Madrid.

Cardich, A.

2014 "Dos Divinidades relevantes del antiguo panteón centro - andino: Yana Raman o Libiac Cancharco y Rayguana”. Investigaciones Sociales, 4 (5). Recuperado de https://doi. org/10.15381/is.v4i5.6847

Carranza, F.

2003 Diccionario Quechua Ancashino-Castellano. Iberoamericana / Vervuert Verlag, Madrid-Frankfurt.

Cerrón-Palomino, R.

1987 Lingüística quechua. Centro de Estudios Regionales Andinos «Bartolomé de Las Casas», Cuzco.

Cobo, B.

1956 [1631] Obras del Padre Bernabé Cobo. Biblioteca de Autores Españoles, Madrid.

Costumbres

2020 (11 de agosto) Flores para el taita (Huancarpata y Cajay/ Provincia de Huari Áncash - Costumbres [video]. YouTube. https://youtu.be/mkQoyfalmCY

Duviols, $\mathrm{P}$.

1986 Cultura andina y represión. Proceso de visitas de idolatrías y hechicerías, Cajatambo, siglo XVII. Centro de Estudios Rurales Andinos "Bartolomé de las Casas", Cusco, Perú.

Duviols, $\mathrm{P}$.

1973 "Huari y Llacuaz. Agricultores y pastores. Un dualismo prehispánico de oposición y complementariedad”. Revista del Museo Nacional, tomo XXXIX: 153-191.

Duviols, $\mathrm{P}$.

2003 Procesos y visitas de idolatría. Cajatambo, siglo XVII. Revisión paleográfica de Laura Gutiérrez Arbulú y Luis Andrade Ciudad, selección de textos y estudios históricos de Pierre Duviols, textos quechuas traducidos, editados y anotados de César Itier. Instituto Francés de Estudios Andinos/Pontificia Universidad Católica del Perú, Lima.

Díaz, A., Galdames, L. y Muñoz, W.

2012 "Santos patronos en los andes. Imagen, símbolo y ritual en las fiestas religiosas del mundo andino colonial (siglos XVI - XVIII)". Alpha, No 35 (Dic. de 2012). Recuperado de http://dx.doi.org/10.4067/S0718-22012012000200003.
Eliade, $\mathrm{M}$

1974 Tratado de historia de las religiones. Artes Gráficas, Madrid.

Escalante, $\mathrm{M}$.

2016 La raíz del mal. Extirpación de la idolatría en el Perú colonial. Pakarina ediciones, Lima.

Espino, G.

2010 La literatura oral o la literatura de la tradición oral. Pakarina, Lima.

García, J.

2015 La racionalidad en la cosmovisión andina. Fondo editorial de la Universidad de Ciencias y Humanidades, Lima.

Griffiths, N.

1998 La cruz y la serpiente: La represión y el resurgimiento religioso en el Perú colonial. Fondo Editorial de la Pontificia Universidad Católica del Perú, Lima.

Hernández Príncipe, R.

1923 [1621] "Mitología andina". Inca I.

Herrera, A.

2016 "El runa Yndio Niscap. tradiciones mítico-históricas andinas registradas en textos escritos para la extirpación de idolatrías y la evangelización: un modo paradójico de persistencia de la religión indígena. Huarochirí, ¿15981608?". Diálogo Andino, (49), 423-442.Recuperado de https://dx.doi.org/10.4067/S0719-26812016000100037

Huerta, J.

2005 Apus y runas. Historias y mitos de los Huaris, Pinkush y Yaros. Instituto Kuntur de Investigación y Desarrollo Andino, Huari, Perú.

Ibarra, B.

2004 Arqueología de la sierra de Áncash. Propuestas y perspectivas. Instituto Cultural RVNA, Lima.

Ibarra, B.

2009 Historia prehispánica de Huari. Desde Chavín hasta los inkas 3000 mil años de historia. Instituto de Estudios Huarinos, Lima.

Ibarra, B.

2016 Arqueología de la sierra de Áncash 2. Población y territorio. Instituto de Estudios Huarinos, Lima.

Lévi Strauss, C.

1968 Antropología estructural. Editorial Universitaria de Buenos Aires, Argentina.

Limón, $\mathrm{S}$.

2017 "Centellas sagradas. El culto al rayo en los Andes centrales". Latinoamérica. Revista de estudios Latinoamericanos" 65. Recuperado de http://dx.doi.org/10.22201/ cialc.24486914e.2017.65.56930. (12 agosto 2019).

López, A. y Millones, L.

2008 Dioses del norte, dioses del sur. Religiones y cosmovisión en Mesoamérica y los Andes. Instituto de Estudios Peruanos, Lima.

Lotman, Y.

1996 La semiosfera I. Semiótica de la cultura y del texto. Trad. Desiderio Navarro. Cátedra, Madrid.

Millones, L.

2008 Perú indígena. Poder y religión en los Andes centrales. Fondo Editorial del Congreso del Perú, Lima.

Ong, W.

1997 Oralidad y escritura. Tecnologías de la palabra. Fondo de Cultura Económica, México. 
Pacheco, C.

1992 La comarca oral. Ediciones La Casa de Bello, Caracas.

Perales, $\mathrm{M}$

2016 "Periplos europeos tempranos y fiestas andinas: un encuentro en Hatun Xauxa y sus implicancias respecto de la tesis de la Alianza Hispano-Huanca”. Diálogo Andino, (49), 181-195. Recuperado de https://dx.doi.org/10.4067/ S0719-26812016000100019

Pino, J.

2004 "El ushnu inka y la organización del espacio en los principales tampus de los wamani de la sierra central del Chinchaysuyu". Chungará. Revista de Antropología Chilena Volumen 36 (2) Recuperado de http://dx.doi.org/10.4067/ S0717-73562004000200005

Robles, Román

"El mensaje de los mitos: Héroes fundadores y origen de los alimentos en la memoria de los pueblos andinos". Revista de Antropología. UNMSM. 2004. Recuperado de https://www.researchgate.net/.../281137654_El_mensaje_de_los_mitos_Heroes_fundado...

Rostworowski, M.

2007 Estructuras andinas del poder. Ideología religiosa y política. Obras completas, tomo VII. Instituto de Estudios Peruanos, Lima.

Sánchez, R.

2014 Apus de los Cuatro Suyos : construcción del mundo en los ciclos mitológicos de las deidades montaña. IEP, Centro Bartolomé de las casas, Lima.
Torero Fernández, A.

1993 "Fronteras lingüísticas y difusión de culto: el caso de Huari y de Contiti Viracocha”. En: Duviols, Pierre. (ed.). Religions des Andes et langues indigènes. Équateur-PérouBolivie avant el après la conquête spagnole. Aix-en-Provence: Publications de I'Université de Provence: 219-233.

Toro, C.

1991 Mitos y leyendas del Perú.A.F.A. Editores importadores S.A., Lima.

Torres, $\mathrm{T}$.

2018 Atando santos. Origen e identidad en la tradición oral. Pakarina Ediciones, Lima.

Venturoli, $\mathrm{S}$.

2011 Los hijos de Huari. Etnografia y Etnohistoria de tres pueblos de la sierra de Áncash, Perú. Fondo de la PUCP, Lima.

Yauri, M.

2016 "Deidades panandinas en el Perú antiguo en el Callejón de Huaylas (Ancash) [Los dioses de Pumacayán]”. Scientia Vol. XVIII (18): 59-70.

Zuloaga, M.

2012 La conquista negociada: guarangas, autoridades locales e imperio en Huaylas, Perú (1532-1610). IEP Instituto de Estudios Peruanos \& IFEA Instituto Francés de Estudios Andinos, Lima.

Zumthor, P.

1989 La letra y la voz. Ediciones Cátedra, Madrid.

Notas

$1 \quad$ Según Zuloaga (2012: 52) "Los habitantes de las guarangas tenían el característico patrón de asentamiento disperso de la mayoría de las sociedades andinas y americanas... Se distribuían en pequeños asentamientos cercanos a sus tierras de cultivo y a sus ganados, que en el mundo andino, según Espinoza Soriano, se denominaban llactas; los españoles los registraron durante sus visitas como pueblos -léase aldeas". Entonces, se evidencia que los runas establecieron sus asentamientos cerca de sus deidades, animales y plantas.

2 Existe información de Yauri (2016) en el sentido que el dios Huari, Guari o Wari es la deidad principal de los llactas, él sostiene que habría sido un importante dios en la cultura Chavín.

3 El mito refiere que en el cosmos solo había humo y de las profundidades de la tierra salieron los amarus. Eran gigantes rojos y con enormes dientes. Cuando se produjo una desavenencia entre el mundo de arriba y el mundo de abajo, hubo un terremoto que ocasionó una inundación en la tierra de los huaris, por lo que salieron huyendo para establecerse en la zona de los Conchucos. Finalmente, degeneraron en hombres, animales y plantas (Toro 1991: 87).

4 Los relatos son producto de la memoria colectiva donde subyacen elementos míticos e históricos. Y el sustento clave es la oralidad. Este término ha sido estudiado por diversos investigadores como Zumthor (1989), Espino (2010), Ong (1997) o Pacheco (1992). En el aporte de los estudiosos quedan especificidades en común: la oralidad es mutable y dinámica. También es contextual e irrepetible, es performativa y lo que trasciende al tiempo y al espacio se identifica como "motivo": portador de las identidades locales y regionales. La oralidad garantiza la reproducción de los mitos y la variación es una forma de trascenderla. Ya Lévi-Strauss (1968: 246) señalaba que "un mito se compone del conjunto de sus variantes". Por eso, la memoria mítica es depositaria de la identidad del grupo, desde los saberes más elementales hasta las explicaciones más complejas respecto de la génesis y desarrollo de las etnias. En tanto que la memoria histórica podría asumirse que es una versión de la contrahistoria, o un testimonio desde la lectura propia de las etnias, que pareciese que no quisieran ajustarse a la versión escrita, que podría denominarse como el discurso hegemónico frente al contrahegemónico de las oraliteraturas. Por eso, a lo largo de las épocas han ido elaborando diversas explicaciones acerca de la invasión española, la extirpación de idolatrías, la imposición de las culturas, las políticas de Estado, las migraciones y los cambios socioeconómicos que han experimentado.

5 La noción de pueblo que empleamos en el presente artículo es equivalente a un asentamiento humano que, por razones históricas, políticas, sociales, económicas, incluso religiosas, se agrupaban los indígenas. La razón es que este concepto de pueblo que tienen los españoles difiere mucho de los asentamientos humanos que estaban formados antes de la invasión. Obviamente, después de esta, también cambiaron drásticamente las configuraciones sociales por la introducción de ordenanzas como las famosas reducciones. Al respecto, Zuloaga (2012:176) propone las siguientes precisiones para el concepto pueblo: 
“-Pueblo prehispánico: aldea dispersa. -Pueblo reducción: corporación política que engloba a una o varias localidades urbanas bajo un gobierno común instalado en uno de ellas, generalmente la cabecera. Es la creada por Toledo durante la década de 1570. -Pueblo dentro de una reducción: una de las localidades urbanas que integraban una reducción toledana, sin gobierno propio. -Pueblo postreducción: una localidad urbana que, si bien inicialmente había formado parte de una reducción, se había independizado políticamente de ella, creando su propio cabildo. Este proceso se fue produciendo generalmente durante las décadas finales del siglo XVI y las del primer tercio del siglo XVII".

6 Cardich (2014) sospecha que el nombre Libiac pudo haber sido adoptado por algún líder de la tribu que haya ocasionado que aparecieran héroes culturales y por tanto la propagación de su veneración. Pero también hubo otros grupos de llakwash que adoraron al hijo de Libiac (sospechamos Ichic Libiac en la versión de Hernández Príncipe o Raria Paucar, Callupa y Nabpara según Robles, 2004), que con otros nombres repitieron los ritos y las ofrendas como si se tratara del dios rayo.

7 A unos 8 kilómetros de Huancarpata hay un pueblo llamado Ushnu, olvidado por los misioneros, donde la cosmogonía de los huaris prevalece en la memoria de los pocos pobladores que habitan. Pero este punto junto con las lagunas Reparin y Purway, se constituyen en pacarinas por donde salieron los amarus y los huaris y luego degeneraron en hombres, plantas y animales. Según Pino (2004: 303), "los ushnus son huecos, subsuelo, ruinas, pircas (muros de piedra), lugares donde se encuentran los muertos, lugares donde están los "gentiles". La información etnohistórica nos refiere que habrían sido estructuras de piedra que sirvieron para realizar los ritos y las ofrendas a sus deidades.

8 Conforme refiere Perales (2016) cuando plantea que muchas imágenes se han configurado sobre la base de la devoción a antiguas huacas. Cita como ejemplo al Señor de Ánimas de Paca en Jauja (Junín, Perú) en cuyo origen se mezcla el mito y el rito milenario.

9 Según Rostworowski (2007: 39-42, 53-56), Illapa o Libiac fue sustituido por el apóstol Santiago. Según la autora, parte de la creencia española que el galope semeja al sonido del trueno.

10 Según la Biblia, el apóstol Pedro se llamó inicialmente Simón. Jesús le cambió el nombre. Pedro proviene de la voz "Petrus" que significa piedra o roca. Jesús en Mateo 16: 13-20 le dice. "Por eso te llamaré Pedro, que quiere decir 'piedra'. Sobre esta piedra construiré mi iglesia, y la muerte no podrá destruirla. A ti Pedro te daré autoridad en el reino de Dios". Además, las alusiones a la piedra o a la roca son permanentes en la Biblia, en libros como Mateo, Juan, Hechos, Corintios, etc. Suponemos que los sermones donde se mencionan estos elementos no les debieron de resultar extraños a los indios, pues muchas de sus wakas eran petrificaciones que provenían de la narrativa de sus memorias históricas y míticas.

11 Señalamos "territorio andino", para referirnos a las informaciones que provienen de la memoria oral.

12 Según Huerta (2005), las illas son "objetos tallados en piedra en forma de animales o en forma natural" (103). Por su parte, Venturoli (2011: 61) señala que "las illas son pequeñas piedras con formas particulares consideradas de buena suerte para la fertilidad de las chacras y de las mujeres". Para García (2015) simboliza el origen de las cosas y de la vida.

13 La voz "yurihua" procede de Yoruba, que viene a ser una etnia que habitó Nigeria en el continente africano. Según la mitología, se cuenta que los yorubas fueron creados por Olodumare, creador supremo. Sin embargo, entre los Orishas también está Shangó o Changó que es considerado el orisha del rayo, el trueno y el fuego. Elementos claves tanto en el mito de los huaris como en el origen del hirka Llamoq.

14 Los actantes danzantes, flores, chicha y feligreses demuestran una subversión al discurso teológico y filosófico de los frailes, pues sus simbolizaciones desbordan ampliamente los rituales católicos.

15 Esta flor es una orquídea de color morado, anaranjado, blanco y rojo. Según la mitología es una bella joven que se rehusó a tener amores con el Asiag y por eso fue condenada a brotar en los bordes de la laguna de Purway en el pueblo de Acopalca. Florece en mayo y junio.

16 La capital de Cajay tiene como patrón a San Pedro. Por mucho tiempo intentaron persuadir a los huancarpatinos para trasladar su imagen al templo de la capital; sin embargo, el pedido fue infructuoso. Por esa razón, fabricaron otra, que se asemejara al de Huancarpata y terminaron repitiendo todas las actividades sociales y litúrgicas. Aunque, circula en el imaginario, la versión que la imagen de San Pedro de Huancarpata no es la original. Se comenta que fue hurtada y sustituida hace mucho tiempo. Este hecho acrecienta el misterio acerca de su narrativa que viene de los siglos XVI y XVII envuelto en un halo mítico y maravilloso.

17 En cuanto a las danzas en la fiesta patronal, sobresalen los huaridanzas que podrían proceder de los llactas. Presumiblemente, habría sido ejecutada durante las festividades en honor al dios Guari. En los movimientos y la coreografía se pueden avistar las edades históricas, las destrucciones y las formas de veneración que se ejecutaban a sus dioses. En el caso de las Pallas, es un baile que se incorpora al rito a Guari producto de la invasión inca y los procesos naturales de superposición que vivieron las llactas. Las pallas son las vírgenes escogidas por el Sol. En la coreografía y las letras que cantan, hay un sustrato de la violencia de la conquista inca y las fracturas que sufrieron los indios con la invasión española.

18 Junior Santiago Córdova, natural de Huancarpata, tiene su cuenta en Facebook donde publica frecuentemente las fotos de San Pedro. Los mensajes que suele acompañar a sus publicaciones son como estos: "Tayta san Pedro de huancarpata el santo patrón que vive aquel que comparta esta imagen de san pedrito sera protejito amigas y amigos los invitamos a compartir cada uno de ustedes" (10 de julio de 2019).

19 En las celebraciones de la liturgia cristiana, sobre todo en los espacios andinos, la gente suele llevar a sus imágenes en distintas representaciones, a quienes consideran como una especie de protectores de la familia, a manera de wakas de las etnias. Este hecho procura la sacralización de sus objetos de culto. En el templo del Señor de la Soledad de Huarás, algunos feligreses llevan agua en baldes o botellas y lo colocan al pie de la imagen durante la misa. Posteriormente, riegan sus negocios, casas y hasta hay quienes se bañan con esas aguas. 
20 Millones (2008: 38-39) señala que las sequías, la falta de pastos para los animales o los conflictos territoriales habrían provocado las guerras y por tanto una reconfiguración socioeconómica, política y religiosa.

21 Muchos santos y santas terminaron siendo destronados cuando no lograban insertarse a los ritos, tradiciones y expectativas de la población. De manera que, en muchos de ellos, los desplazamientos han terminado con los santos originales prácticamente invisibilizados. Muestra de esta afirmación está en Chiquián, capital de la provincia de Bolognesi (Áncash) donde San Francisco ha sido desplazado por Santa Rosa de Lima e incluso reducido a un culto exclusivamente marginal. Lo mismo se puede decir de San Sebastián, patrón de Huarás, desplazado en algún momento de su historia por el Señor de la Soledad. Los ejemplos se pueden extender a la provincia de Huaylas, en su capital Caraz. Ahí, la Virgen de Chiquinquirá destronó a San Ildefonso . Las razones de estos hechos desbordan a los objetivos de este trabajo. Sin embargo, lo que quiero puntualizar es que en el caso de San Pedro de Huancarpata, pese a que hay muchas imágenes que le rodean como el Señor de los Milagros, la Virgen del Rosario, los famosos "mellizos" (dos imágenes pequeñas de San Pedro y San Pablo), San Juan, Santa Rosa de Lima, San Antonio y San Nicolás; ninguna ha logrado desplazarlo. Este hecho se podría transformar en un argumento más que refuerce la importancia del hirka Llamoq en el imaginario huarino. 